\title{
Television, sustainability and subjective wellbeing in Peru
}

\author{
Monica Guillen-Royo \\ TIK, University of Oslo
}

\section{Introduction}

Watching television is a major leisure activity around the world. Despite competition from on-line sources, most people still turn to TV for entertainment and for information. Also younger generations are keen viewers, spending on average 2.5 hours a day watching TV. ${ }^{1}$ The pervasiveness and influence of television on attitudes, values and behaviours has made the study of its impact on quality of life a prominent research topic, with most studies indicating a negative relationship between television consumption and wellbeing ${ }^{2}$ (Stanca, 2016). Further, with the continuing promotion of material affluence and luxury in TV programmes and advertisements, together with scanty environmental content, heavy viewing has been found to correlate with reduced concern about the natural environment, lower pro-environmental attitudes and lack of engagement in proenvironmental behaviours (Good, 2009; Shanahan and McComas, 1999).

Understanding the role of television in promoting or obstructing sustainable practices is a matter of urgency, in view of the global imperative to reduce material demands in order to keep temperature rise below the $2^{\circ} \mathrm{C}$ mark (Allwood et al., 2011; UNFCCC, 2015), and the international commitment to meet the targets of the UN Sustainable Development Goals (UN 2015). The concept of sustainable development, as defined by the World Commission on Environment and Development (WCED), ${ }^{3}$ calls for analyses of consumption patterns in terms of their effects on the wellbeing of current and future generations. Thus, policies addressing TV consumption from an environmental perspective must also account for the impact on the wellbeing of the viewers. This is relevant in terms of feasibility as well: for example, advocating a reduction in hours of viewing would be easier if television were found to have a clearly negative effect on wellbeing.

Research on the simultaneous impact of consumption practices on current generations' wellbeing and how their pro-environmental behaviour or attitudes may affect future generations is still scarce (Verhofstadt et al., 2016). The few studies have focused on prosperous countries - in line with the general view that Western consumers, who are responsible for most greenhouse gas (GHG) emissions, should bear the burden of a change in consumption patterns. However, many poor and middle-income countries present pockets of wealth and high levels of socio-economic inequality particularly in Latin America, the region with the highest levels of income inequality in the world (Lopez-Calva and Lustig, 2010). Here television might serve to disseminate the 'high-flying' lifestyles of the rich, thereby promoting unsustainable consumption practices as a goal for poor and middleincome groups.

The present study contributes to the limited but emergent literature on consumption practices and sustainability by analysing the relationship between television consumption, sustainable attitudes and happiness in one upper-middle income country in South America. Peru has an economy largely based on the exploitation of hydrocarbons and minerals. Its rapid economic growth (average growth

\footnotetext{
${ }^{1}$ For data on young people's viewing habits see: http://www.worldtelevisionday.tv/young-and-tv/ (accessed 27.07.2017).

2 In this section, 'quality of life' and 'wellbeing' are used interchangeably as umbrella terms encompassing the objective and subjective dimensions of wellbeing.

${ }^{3}$ The WCED defined Sustainable Development (SD) as 'development that meets the needs of the present without compromising the ability of future generations to meet their own needs' (WCED, 1987:43)
} 
rate $5.9 \%$ between 2002 and 2013) has been accompanied by a reduction of the poverty rate (from $59 \%$ in 2004 to $22 \%$ in 2015), but also a doubling of $\mathrm{CO}_{2}$ emissions per capita (from 0.98 to 1.87 tons), and a doubling of private vehicle ownership and residential electricity consumption (INEI, 2017; World Bank, 2017). Nevertheless, inequality remains high: 50\% of those living in Peru's rural highlands live under the poverty line, and $15 \%$ of the rural population is illiterate (INEI, 2015b). Almost every household in Peru watches television (87\%), and most people in major cities and among the wealthiest groups report watching it daily (CONCORTV, 2015; INEI, 2015a).

This study investigates the relationship between television consumption, sustainability and wellbeing, drawing on primary data from a heterogeneous sample in Peru. The article begins by outlining the main findings of the empirical literature on the relationship between television viewing, pro-environmental attitudes and wellbeing. Next, it presents the hypotheses, data and methodology of the empirical study, followed by the main findings. The concluding section offers reflections on the implications for sustainability policy.

\section{Literature background}

\subsection{Television and sustainability}

Studies analysing the content of television programmes indicate over-portrayal of extreme situations like violence, corruption, murder and luxurious lifestyles, and under-representation of issues regarding climate change and the natural environment (Fiske, 1987; Gavin and Marshall, 2011; McComas et al., 2001; Smith 2017). Most of these studies concern OECD countries, but researchers analysing Latin America, and Peru in particular, likewise note the prevalence of soap operas and entertainment programmes emphasizing celebrity lifestyles, consumerism and luxury, as against the limited presence of environmentally related topics (CONCORTV, 2015; Galhardi et al., 2015; Kottak, 2016; Martinez Garza, 2005). This is most detrimental for heavy viewers, who are more likely to draw on television in interpreting and understanding their everyday reality (Gerbner and Gross, 1976). Heavy viewers will be inclined to equate the good life with the frequent acquisition of products and services; they will also be more likely to aspire to high levels of consumption, financial success and popularity, while de-prioritizing sustainable consumption practices (Harmon, 2001; Nairn et al., 2007; Shrum et al., 2005; Sirgy et al., 1998).

Materialism as promoted by television may be particularly harmful for sustainability. At the individual level, materialism is associated with personal values and aspirations which are heavily influenced by messages from people's socio-economic and cultural environments and the mass media (Kasser, 2002; Richins and Dawson, 1992). Materialistic values could thus be seen as a mediating factor or intervening variable in the relationship between television consumption and proenvironmental attitudes or behaviours. The role of materialistic values as mediators was investigated by Good (2007) in her study of the effects of television viewing on attitudes about the natural environment in the US. Following Baron and Kenny's $(1986)^{4}$ four-step procedure for studying mediation, Good found that television viewing was a negative predictor of pro-environmental attitudes (step 1), and was positively associated with materialistic values (step 2). Further, when environmental attitudes were regressed on materialism and television viewing, materialism was negative in explaining attitudes (step 3); but watching television was no longer a significant predictor (step 4). Good held that these results provided empirical evidence of the negative effects of heavy

\footnotetext{
${ }^{4}$ Baron and Kenny's (1986) procedure is based on four steps for the study of mediation based on regression analysis results. The first step aims at showing that the independent variable predicts the dependent variable (television viewing predicts environmental behaviours). The second establishes that the independent variable explains the mediator (television viewing predicts materialism). The third and the fourth are studied in the same equation and show that the mediator predicts the dependent variable and that the independent variable is no longer explaining the dependent as the mediator is controlled for (the coefficient of television viewing should not be significantly different from zero).
} 
television viewing on attitudes towards the environment through TV promotion of materialistic values.

The negative relationship between materialism and pro-environmental attitudes or behaviours is a consistent finding across samples and contexts. Kasser and colleagues have studied materialism through the emphasis people put on extrinsic goals (for financial success, image and popularity) as opposed to intrinsic goals (self-transcendence, physical health, affiliation and community) (Kasser and Ryan, 1993, 1996; Kasser, 2002; Kasser, 2016). They find that a relative focus on extrinsic goals is associated with engaging in fewer sustainable behaviours like reusing materials, recycling and riding bicycles, as well as with higher ecological footprints (Brown and Kasser, 2005; Hurst et al., 2013). Moreover, experimental evidence supports the causal path from values to sustainability. For example, Sheldon and colleagues (2011) found that US college students, if briefly prompted about intrinsic values, made policy recommendations that were more sustainable than did those who were prompted about extrinsic values. Conversely, Chilton and colleagues (2012) found that reflecting on intrinsic values led highly extrinsically-oriented Welsh adults to express greater concern about climate change.

\subsection{Television and wellbeing}

The concept of wellbeing concerns the appraisal of a person's situation. This can be done directly, by asking the person concerned (Subjective Wellbeing - SWB), or indirectly, by assessing the extent to which certain requirements for a fulfilling life are met (Objective Wellbeing - OWB) (Gasper 2005). Research on the effects of television on wellbeing has tapped on its many dimensions; from the effects of viewing on moods, feelings and levels of satisfaction through its impact on the basic needs for health or relatedness, for example. A reference study is Kubey and Csikszentmihalyi's (1990) Television and Quality of Life, addressing the relationship between ì watching television and several measures of wellbeing, with data from US, Canadian, German and Italian samples. Their research was based on the Experience Sampling Method, tracking people's activities for one week and asking at random times questions about their activities and the wellbeing experienced. The authors concluded that watching TV was positively related with negative feelings (although they noted that television viewing could be more a response to negative affect than the cause of it) and was negatively linked with personal states such as feeling alert, active and challenged by the activity.

Recent studies on the relationship between television viewing and wellbeing have provided additional evidence of a negative relationship. Two of the most influential contributions - Frey et al. (2007) and Bruni and Stanca (2008) - have, in addition to confirming the direct negative impact of heavy viewing on wellbeing, investigated factors that might mediate the relationship. Drawing on data from the 2002/2003 European Social Survey, Frey and colleagues (2007) concluded that heavy viewers (watching television more than 2.5 hours a day) experienced lower levels of wellbeing than those who watched TV for less than 0.5 hours a day because watching television reduced their satisfaction with their financial situation, increased the importance given to affluence, reduced their trust in others and their feeling of safety and made them less active socially. Using data from the first four waves of the World Values Survey (WVS), Bruni and Stanca (2008) explored whether watching television was crowding out the time people spent with others or engaged in voluntary organizations. They found that heavy viewing (more than 2 hours) reduced the probability of participating in voluntary organizations and spending time with friends - two activities positively associated with life satisfaction.

Other studies have found results similar to those of Frey and colleagues, particularly concerning the role of materialistic values and aspirations in mediating the negative relationship between television viewing and SWB (Burroughs et al., 2002; Shrum et al., 2011; Sirgy et al., 1998). The extent to which these findings imply a causal path from TV viewing through materialism to subjective wellbeing has been tested only partially. Recent studies, like Hyll and Scheider (2013) and Shrum and colleagues 
(2011), offer experimental evidence of a causal effect running from television viewing to material aspirations, and Kasser (2016) presents evidence from experiments suggesting a causal effect running from materialistic values and goals to negative affect, pleasurable feelings and happiness. However, the full causal path from TV consumption through materialism to wellbeing has not been tested in any comprehensive experimental study. Thus, it could still be argued that unhappy people are more attached to material possessions and consequently watch more television than do their happier counterparts.

Finally, a null or positive direct relationship between watching television and wellbeing cannot be ruled out in certain contexts. Various controversial methodological choices in the study by Bruni and Stanca (2008) using WVS data for 38 countries led Kataria and Regner (2011) to replicate the analyses. For many countries, including Peru, they found a non-significant link between heavy television viewing and wellbeing, whereas the relationship was positive in others. The latter finding was compatible with Graham and Nikolova's (2013) suggestion of a positive relationship between access to television and people's moods and everyday experiences in poor and middle-income countries. In these contexts, television could serve as a major source of information, whereas alternative leisure activities might be greatly restricted because of the limited access to travel, organized sports, cinema, museums or even magazines and books. Watching TV may be one of the few luxuries many people in poor and middle-income countries can experience on a daily basis, and a negative relationship between viewing and wellbeing should not necessarily be expected.

\subsection{Television in Peru: the present study}

In Peru as elsewhere, television remains the most-used source of information and entertainment, despite the spread of internet and the extensive coverage provided by mobile phone networks (CONCORTV, 2015; Fuentes et al., 2016). On average, Peruvians watch television 3 hours 20 minutes a day, although there are important variations across economic groups and regions (INEI, 2015a; Latinlink, 2013). Of Peru's 1,491 television stations, $26 \%$ are publicly owned and $58 \%$ are classified as commercial (CONCORTV, 2017). Subscription-based TV and internet are increasingly popular among Peruvian households. However, this is still limited to cities, where subscription-based television reaches $62 \%$ and internet $43 \%$ of households. In general, the most viewed programmes are soap series, reality shows and news programmes, mainly from nationwide commercial television channels. Peruvians consider programmes on traditional television channels (commercial and non-commercial) to be more sensationalist and less educational than those available on subscription-based television and internet (CONCORTV, 2015).

Research on the relationship between television viewing, sustainability and wellbeing is still in its infancy in Peru. According to a report concerning viewers opinionss in 20 Peruvian cities, people feel that television presents positive images of programme leaders, political parties, government authorities, businesspersons and football players/sportsmen and negative images of women, the elderly, children and indigenous minorities respectively (CONCORTV, 2015). The study highlights that people see TV programmes as being biased toward the rich and powerful, and against the weak and minority groups, and that many situations or parodies on television programmes offer bad examples for society. In addition, empirical studies find a negative relationship between TV viewing and health, particularly regarding overweight, obesity and the unhealthy eating habits among young people in Peru (Jakoby et al., 2003; Poterico et al., 2012; Sevillano and Sotomayor, 2011).

This article explores the direct and indirect relationships between television, sustainability and subjective wellbeing. The first hypothesis concerns the direct relationship between television consumption, sustainable attitudes and wellbeing. In line with studies based on US data (Good 2007,2009; Shanahan and McComas 1999), the relationship between TV viewing and proenvironmental attitudes should be expected to be negative, as the content of television in Peru does not seem to differ much from that in other countries as regards the presentation of environmentally 
related topics and the prevalence of consumerism (CONCORTV 2013, 2016; Mateus, 2008). However, and in line with Kataria and Regner's (2010) study using WVS data, the negative relationship to subjective wellbeing found in other samples will not necessarily apply where alternative forms of information and entertainment are not widely available - as in certain areas of Peru.

The second hypothesis connects to the general agreement in the literature, that materialistic values or goals mediate the relationship between television consumption and sustainable attitudes and wellbeing (Good, 2007; Shrum et al., 2011). More hours of TV viewing are hypothesized to entail greater exposure to commercials, programmes, films and soap series emphasizing values associated with celebrity lifestyles, luxury, competition and status. This is expected to reduce people's wellbeing as well as their concern with the environment, thus mediating in the relationship between television consumption and the two outcome variables.

\section{Survey and data}

Survey data were collected through a questionnaire distributed to 569 people from five Peruvian districts between August and November 2011. The survey was part of a larger research project on sustainable development, personal values and wellbeing in Peru and some of the data have already been reported in Guillen-Royo and Kasser (2015). Districts were selected to reflect the diversity in the country, in line with the APEIM (2011) classification of socio-economic groups. Three districts in Lima represented upper-middle-income (Miraflores), lower middle-income (Breña) and low-income (Huaycan - Ate Vitarte) neighbourhoods in the capital city. Two districts in the central highlands Acostambo (low-income rural Andean) and Huancayo (lower middle-income urban Andean) - added a geo-political dimension to the sample.

Participants were selected through non-random quota sampling following the classification by age group and gender in each district from the 2007 national census. ${ }^{5}$ All were aged 18 and over, and only one individual per household was approached. The survey had sections on personal goals, sustainable attitudes, subjective wellbeing, and demographic/socio-economic data. Most people were able to complete it in 20-30 minutes. Of the 569 questionnaires collected, 500 were used for the analysis, after cleaning the data and balancing the sample to reflect age and gender distribution in each district.

\subsection{Measures}

Television viewing. The quantity of television viewed by a person was assessed with an open-ended question on the number of hours the respondent watched television on a normal day: 'On average, how many hours per day do you watch television?'. Open-ended questions on television viewing have been criticized due to people's inaccurate recollection of the time spent on the activities they engage in (Good, 2007). However, the correlation between hours of television viewed and alternative scales on the level of viewing is usually high (Shrum et al., 2011), and respondents did not report difficulties that would have justified changing the type of question.

Sustainable attitudes. Sustainable attitudes were approximated through responses to four types of social scenarios where participants indicated their preference between more / less ecologically sustainable practices concerning transport, work and expenditures, the use of natural resources, and food consumption (see Table 1). Scenarios were chosen after discussion with local researchers and after piloting the questionnaire in Lima. Transportation and food consumption represented two consumption domains where sustainable alternatives existed and were familiar to participants. The work-and-spend cycle as a definition of consumerist life-styles was easy for participants to identify, as were alternative ways of exploiting the country's natural resources. However, it became clear that farmers and others with a background in agriculture (mainly from Acostambo, Huancayo and

\footnotetext{
${ }^{5}$ Data from the 2007 national census is available on-line at http://www.inei.gob.pe.
} 
Huaycan), did not associate local and organic products with more expensive fruits and vegetables, so responses to the food-related scenario were dropped from the analysis.

Table 1. Sustainability scenarios

\begin{tabular}{|c|c|}
\hline $\begin{array}{l}\text { Concerning mean of transportation, would } \\
\text { you rather live in: }\end{array}$ & $\begin{array}{l}0 . \quad \text { a society where most people have cars } \\
\text { 1. a society where most people use an efficient public transport } \\
\text { system, bicycles, or walk }\end{array}$ \\
\hline $\begin{array}{l}\text { Concerning work-and-spending, would you } \\
\text { rather live in: }\end{array}$ & $\begin{array}{l}\text { 0. a society where people work more than } 8 \text { hours a day and have high } \\
\text { salaries with which they buy everything they wish } \\
\text { 1. a society where people work up to } 8 \text { hours a day and have salaries } \\
\text { that cover basic needs as defined by the population }\end{array}$ \\
\hline $\begin{array}{l}\text { Concerning natural resource management, } \\
\text { would you rather live in: }\end{array}$ & $\begin{array}{l}\text { 0. a society that makes a lot of money from intensively exploiting its } \\
\text { natural resources } \\
\text { 1. a society that makes a moderate amount of money, limiting natural } \\
\text { resource exploitation for social and environmental reasons }\end{array}$ \\
\hline $\begin{array}{l}\text { Concerning food consumption, would you } \\
\text { rather live in: }\end{array}$ & $\begin{array}{l}\text { 0. a society with a diet based on cheap products of diverse origins } \\
\text { 1. a society with a diet based on moderately priced local and organic } \\
\text { products }\end{array}$ \\
\hline
\end{tabular}

The Sustainable Attitudes (SA) scale was generated by computing the average score of the first three scenarios. To test the validity of this measure, the resulting SA scores were correlated with the responses to another question in which participants identified how they would define progress, using one or a combination of three factors (economic situation, socio-economic inequalities, and the state of the environment). SA scores were positively and significantly correlated with a binary variable capturing whether respondents would include the environmental situation in their definition of progress $(r=0.1587, p<0.01)$ and negatively correlated with a binary variable addressing the inclusion of the economic situation in the definition of progress $(r=-0.1591, p<0.01)$.

Subjective wellbeing. Respondents' wellbeing was captured through two variables and a scale that tapped into the affective, the cognitive and the eudemonic dimensions of wellbeing, respectively. ${ }^{6}$ The affective dimension was approximated by a single-item question asking about the extent to which respondents felt generally happy or unhappy, ${ }^{7}$ with answers on a 5-point semantic scale from 'very happy' (5) to 'very unhappy' (1). The cognitive dimension was assessed through a question on the extent to which respondents felt satisfied with their life as a whole, on a five-point scale from very satisfied' (5) to 'very dissatisfied' (1). The third measure was a Subjective Vitality Scale (SVS) consisting of six statements ${ }^{8}$ where respondents were to indicate the degree to which these statements appeared true in general as regards their lives (Ryan and Frederick, 1997). As expected the three SWB measures were positively associated, with happiness correlating moderately with life satisfaction and the SVS $\left(r^{P}=0.33, p<0.001\right)$, and life satisfaction and the SVS showing a lower level of association $\left(r^{P}=0.24, p<0.001\right)$

\footnotetext{
${ }^{6}$ Following Eid and Diener (2004) subjective wellbeing encompasses both cognitive judgments of life satisfaction and affective assessments of moods and emotions. Subjective vitality taps on the extent to which people can function adequately in their socio-economic and environmental context and thus are able to fulfill their psychological needs (Ryan and Frederick, 1997). Past literature suggests that happiness and life satisfaction correlate quite closely (Graham, 2009) and that their tendency is to evolve in the same direction and not in a divergent one (Easterlin, 2013). In many studies both concepts are used interchangeably (Frey and Stutzer 2002). Regarding SVS, Ryan and Frederick (1997) indicate that subjective vitality relates negatively to measures of negative emotions such as anxiety, which in turn is negatively correlated with measures of positive affect such as happiness.

${ }^{7}$ In Spanish: '¿En general como se siente normalmente de feliz/infeliz?

${ }^{8}$ The six items of the subjective vitality scale were: 1) I feel alive and vital; 2) Sometimes I feel so alive I just want to burst; 3) I have energy and spirit; 4) I look forward to each new day; 5) I nearly always feel alert and awake; 6) I feel energized. Answers were given using a five-point scale (from 'not at all true' $=1$ to 'very true' $=5$ ) and the SVS variable was calculated averaging the answers to the six statements (Ryan and Frederick, 1997).
} 
This paper uses happiness as the indicator for SWB in the main regressions because of the higher risk of 'common method bias' (whereby common variance between subjective variables can be attributed to their being collected in the same instrument) associated with the SVS and the life satisfaction variables. A Harman's single-factor test indicated that only the happiness variable loaded on a different factor than personal goals (the main attitudinal variables included in the survey besides the SWB variables), thus presenting a lower risk of common method bias and subsequently of measurement error (Podsakoff et al. 2003). Nevertheless, the empirical study was run with the three SWB variables; results for the life satisfaction and the SVS regressions are included in the appendix (Table A.3) and discussed in sections 4.1 and 5.

Personal goals. Participants' values were addressed drawing on Kasser and Ryan's (1996) Aspiration Index of 42 closed-ended questions on intrinsic goals (personal growth, affiliation, community feeling) and extrinsic ones (financial success, image and popularity). The importance of each goal was rated on a scale from 1 ('not at all important') to 5 ('extremely important'). After factor analysis, 34 items that loaded above 0.4 on one of the subscales were retained. Items of the self-acceptance and affiliation categories loaded on the same factor and were analysed jointly. Higher-order factor analysis ${ }^{9}$ conducted on the six subscales resulted in two factors consistent with the intrinsic and extrinsic goals classification: goals of self-acceptance/ affiliation, community feeling, and physical fitness loaded on one factor, while goals of financial success, attractive appearance, and social recognition loaded on another. Subscale scores were used for the econometric analysis, as high levels of inequality and socio-ethnic fragmentation could result in some goals having a different relation to wellbeing than that indicated in earlier studies (Copestake, 2008; Guillen-Royo and Kasser 2005).

Control variables. Demographic (age, gender, civil status, mother tongue, place of residence, etc.) and socio-economic (education and income) characteristics and health status were included as controls in the regression analysis (see descriptive statistics in Table A.1 in the appendix). Personal income was captured through a list of eight income brackets in the local currency (Peruvian Sol, PEN). The lowest category matched the net monthly household income of the poorest $5 \%$ (less than PEN 300 ) and the highest category the income of the richest $1 \%$ (more than PEN 10,300). In line with McBride (2001), household income was transformed from categorical to continuous by calculating the average value of the income category selected by respondents. The average monthly incomes of the poorest 5\% (PEN 150) and of the richest 1\% (PEN 17,583) in Peru in 2010 (INEI, 2010) were used as lower and upper thresholds, respectively. Household income was transformed to per capita terms by dividing it by the square root of the number of household members, using the OECD (2008) square root equivalence scale. Finally, the natural logarithm of the personal income variable was computed, to account for the decreasing marginal utility of income (Clark et al. 2008).

The following general specifications were used to study whether television viewing $\left(T_{\mathrm{i}}\right)$ plays a role in explaining the sustainable attitudes $\left(S A_{i}\right)$ and happiness $\left(H_{i}\right)$ of individuals accounting for personal and socio-economic characteristics $\left(X_{i}\right)$ and district of residence $\left(D_{i}\right)$.

$S A_{i}=B_{0}+B_{1} T V_{i}+\gamma_{1} X_{i}+\gamma_{2} D_{i}+\varepsilon_{i}$

$H_{i}=B_{0}+B_{1} T V_{i}+\gamma_{1} X_{i}+\gamma_{2} D_{i}+\varepsilon_{i}$

Baron and Kenny's (1986) four-step procedure was used to test the second hypothesis, on the role of materialistic goals as mediator. Step 1 was tested by regressing SA/H on television viewing, Step 2 by regressing personal goals on television viewing, and steps 3 and 4 by regressing SA/H on both personal goals and television viewing, controlling for relevant personal and socio-economic variables in all regressions. Thereafter, a Sobel (1982) test was run to confirm the effect and obtain the

\footnotetext{
${ }^{9}$ Factor analyses were conducted using principal component analysis with varimax rotation and Kaiser normalization.
} 
proportion of the relationship between television viewing and the dependent variable mediated by materialistic goals.

\section{Results}

Table 2 presents average television ownership, hours of viewing, sustainable attitudes scores and happiness scores, by district and for the whole sample. As expected from official data, most people reported living in households with at least one television set. The average amount of time spent watching television was 2 hours and 42 minutes - below the 3 hours 20 minutes estimated by CONCORTV (2013) using only urban data. Differences between districts were not significant (using ANOVA, post-hoc Scheffe) except for the lower-middle income district of Breña, where people reported watching TV for almost 4 hours daily. Concerning attitudes, people in wealthy Miraflores were significantly more sustainability-oriented than those living in the slum (Huaycan) and the rural Andean highlands (Acostambo), but not significantly different from those living in Breña and Huancayo, two urban lower-middle income sites. No significant differences were found in happiness scores across districts. In general, those who watched more television scored lower in the sustainable attitudes scale $\left(r^{p}=0.10, p<0.05\right)$, but no significant relationship was found between happiness scores and hours of viewing before controlling for the socio-demographic, economic and personality variables included in the regression models (Table 3 ).

Table 2. Television, sustainable attitudes and happiness

\begin{tabular}{|c|c|c|c|c|c|c|}
\hline & District & $\begin{array}{l}\text { Personal } \\
\text { income } \\
\text { (district } \\
\text { average) }^{\mathrm{a}}\end{array}$ & $\begin{array}{l}\text { TV ownership } \\
\text { by district }\end{array}$ & $\begin{array}{c}\text { Average } \\
\text { hours of } \\
\text { TV } \\
\text { viewing }\end{array}$ & $\begin{array}{c}\text { Average } \\
\text { Sustainable } \\
\text { Attitudes } \\
\text { Score }\end{array}$ & Happiness \\
\hline \multirow{3}{*}{ 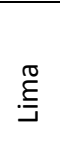 } & Miraflores & 2,600 & $99 \%$ & 2.3 & 0.83 & 3.66 \\
\hline & Breña & 640 & $99 \%$ & 3.7 & 0.73 & 3.52 \\
\hline & Huaycan & 476 & $99 \%$ & 2.7 & 0.65 & 3.67 \\
\hline \multirow{3}{*}{$\begin{array}{l}\frac{n}{0} \\
\frac{0}{0} \\
\frac{\pi}{\frac{1}{0}} \\
\frac{000}{1}\end{array}$} & Huancayo & 608 & $98 \%$ & 2.6 & 0.73 & 3.63 \\
\hline & Acostambo & 139 & $89 \%$ & 2.0 & 0.63 & 3.56 \\
\hline & Entire sample & 895 & $97 \%$ & 2.7 & 0.71 & 3.61 \\
\hline
\end{tabular}

a Data in Peruvian Sol. In November 2011, 1 Peruvian Sol corresponded to approximately 0.37 US Dollars.

Models 1 and 2 introduced in section 3.1 were estimated in two steps in order to test the hypotheses. First, the basic model investigating the direct relationship between television viewing and the two outcome variables was estimated (model a). Then, goal subscales were included in the regression to explore the mediating role of personal goals (model b). Following Good's (2007) research on television viewing in the USA and Guillen-Royo and Kasser's (2015) study of personal values and happiness drawing on the same Peruvian sample, sex, age, civil status, education, income, language and district of residence were used as control variables. To account for the ordinal nature of the two dependent variables, two specifications were estimated: the first applying an ordinary least square (OLS) estimator, and the second using an ordered probit model. Since the relative size and significance of the estimators did not differ notably between specifications, and least squares coefficients are easier to interpret, the results presented in Table 3 and the discussion hereafter are based on the OLS estimation. ${ }^{10}$

\footnotetext{
${ }^{10}$ Ferrer-i-Carbonell and Frijters (2004) indicate that results of wellbeing estimations are not sensitive to the choice of method. All OLS estimations presented here used robust standard errors. The potential instability of predictors due to multicollinearity was investigated through the collinearity statistics available in STATA/SE 15.2 .
} 
As shown in Table 3, neither in specification (a) nor in specification (b) did any of the variables capturing individuals' characteristics emerge as significant predictors of sustainable attitudes. Using Miraflores, the upper-middle class district of Lima, as the district of reference, living in the other four districts proved to be a negative predictor of sustainable attitudes. This relationship was particularly strong in rural Acostambo and Huaycan, the slum of Lima, indicating that infrastructural and cultural characteristics of the locations might influence residents' attitudes towards sustainable alternatives regarding transport, lifestyle and resource management. The sign and significance of the coefficients of respondents' socio-economic characteristics and district of residence in the happiness regressions (specifications $a$ and $b$ ) were similar to those found in previous studies on wellbeing determinants in Peru (Bechetti et al., 2011; Graham and Pettinato, 2002; Herrera et al., 2006). They were also comparable to those of Guillen-Royo and Kasser (2015) drawing on the same data-set, where people experiencing separation or divorce and those without formal education reported lower levels of happiness, whereas those with Quechua as mother tongue ${ }^{11}$ with postgraduate education and/or in good health considered themselves happier. Personal income and living in the three districts outside central Lima (Huaycan, Huancayo and Acostambo) were also positive determinants of happiness. ${ }^{12}$

As shown in Table 3, and parallel to findings in previous studies, the more hours that respondents spent watching television, the lower were their sustainable attitudes. To explore this finding further, model (a) was re-run with the variable hours of television viewing transformed into a categorical variable (no viewing; less than the sample average of 2.7 hours; and more than 2.7 hours) and with the model including a quadratic term exploring the possibility of a diminished negative effect of viewing with increased television consumption. Results presented in Table A.2 in the Appendix indicate that compared to those who watch TV less than 2.7 hours, heavy viewers were $8 \%$ less sustainability-oriented. They also suggest that the relationship between television consumption and sustainable attitudes might be non-linear: the quadrating term has a positive and significant coefficient, indicating minimum inclination towards sustainability at 7 hours and 10 minutes of viewing. Concerning happiness, and contrary to findings from some wealthy countries, estimation results indicate no direct relationship between TV consumption and happiness in Peru. This applies to the linear effect of hours of television watching on happiness (Table 3, specification a) and to the exploration of the non-linear effects (quadratic term and categorical variable) shown in Table A.2.

Table 3. Television viewing, sustainable attitudes and happiness (OLS)

\begin{tabular}{lcccc}
\hline & \multicolumn{2}{c}{ Sustainable attitudes } & \multicolumn{2}{c}{ Happiness } \\
\hline & (a) & (b) & (a) & (b) \\
\hline $\begin{array}{l}\text { Television } \\
\text { Hours of viewing (daily) }\end{array}$ & $-.0133^{* *}$ & -.0086 & .0254 & $.0329\left(^{*}\right)$ \\
& & & & \\
Personal goals & & & & .0294 \\
Self-acceptance and affiliation & & $.0718\left(^{*}\right)$ & .0095 & $.2665^{*}$ \\
Community feeling & & .0084 & & -.1251 \\
Physical fitness & & &
\end{tabular}

\footnotetext{
${ }^{11}$ Quechua is the indigenous language spoken in the central Andean highlands and by many urban migrants in the sample. It identifies respondents with an indigenous background, often associated with a greater disposition to express positive feelings (Copestake, 2008).

12 This finding should be taken with caution. The fact that locations were chosen to represent the socioeconomic and geographic heterogeneity of the country implies that a third variable like wealth might be jointly determining the results. When Guillen-Royo and Kasser (2015) instrumented the variable personal income using the same data-set, both personal income and the location variables became non-significantly different from zero.
} 
Financial success

Attractive appearance

$-.0995^{* *}$

$-.1686\left(^{*}\right)$

Social recognition

$-.0333$

.0540

Personal characteristics

Age

Female

$-.0200$

$-.0112$

Cohabiting

Separated/divorced

.0007

.0005

.0022

.0028

$-.0037$

$-.0075$

.0399

.0098

.0191

.0201

.0443

.0477

Widowed

$-.0270 \quad-.0296$

$-.3007(*)$

$-.2944\left(^{*}\right)$

Health status

$-.0547$

$-.0393$

.1579

.1878

Education (no level)

$-.0168$

$-.0100$

$.2369 * *$

$.2484 * *$

Education (primary)

.0215

.0520

$-.7412^{* *}$

$-.6063 *$

$-.0701 \quad-.0713$

$-.0767$

$-.0446$

Education (secondary)

$-.0472$

$-.0389$

$-.1035$

$-.0750$

Education (higher non-university)

$-.0018$

$-.0068$

.0151

.0054

Education (postgrad)

$-.0315$

$-.0152$

$.2929 *$

.2986*

Mother tongue (Quechua)

.0319

.0403

$.2687(*)$

$.2954 *$

Income

Personal income

.0043

$-.0023$

$.1101 *$

$.1120^{*}$

Location

Breña

$-.073$

$-.0445$

.0765

.1101

Huaycan

$-.1694 * *$

$-.1366 * *$

$.3639 *$

$.3948 *$

Huancayo

$-.1118^{*}$

$-.0457$

$.3138^{*}$

$.4398^{* *}$

Acostambo

$-.2090 * *$

$-.1369 *$

$.3753(*)$

$.5175 *$

Constant

$.8771^{* *}$

$.9312 * *$

$1.5997^{* *}$

1.1203

Observations

468

468

475

475

$\mathrm{R}^{2}$

0.0906

0.1704

0.1054

0.1289

Notes: Reference group for civil status is single, for education is university graduate and for location is the district of Miraflores.

$* *$ significant on $99 \%$ level, ${ }^{*}$ significant on $95 \%$ level, $\left({ }^{*}\right)$ significant on $90 \%$ level.

Tables 3 and 4 present the results of applying Baron and Kenny's (1986) four-step procedure for the study of mediation to investigate the role of personal goals as intervening factors. Model (a) in Table 4 suggested a negative effect between television viewing and sustainable attitudes and a nonsignificant effect of viewing on happiness (step 1). Regressing personal goal subscales on television consumption (Table 4) indicated that only the goal of financial success was significantly (and positively) correlated with watching television (step 2). The role of financial success as mediator in the relationship between television consumption and sustainable attitudes was further explored in specification (b), where all goal subscales were introduced in the model. As Table 3 shows, the coefficient of the goal of financial success is negative and significant (step 3) and the coefficient of television consumption becomes non-significantly different from zero (step 4), indicating complete mediation (Baron and Kenny, 1986).

Mediation was not investigated regarding happiness, as step 1 of the Baron and Kenny procedure represented in specification (a) did not yield significant results for the coefficient of television consumption. However, the fact that in specification (b) television consumption became a marginally significant and positive predictor of happiness indicated that financial success could be acting as a suppressor variable. Thus, the personal goal of financial success might be conveying the negative effect of television on happiness (MacKinnon et al., 2007) suggesting a positive, albeit only marginally significant, effect of television viewing on wellbeing in the Peruvian sample. Following earlier research arguments of a positive relationship in contexts where alternatives for cheap entertainment and information are limited, model (b) was re-run: first, including an interaction term resulting from multiplying TV consumption and district of residence; and second, analysing the model by district of 
residence (results not shown here). No significant relationships were found in any of the estimations, except when model (b) was analysed with data from the Lima slum of Huaycan, where a marginally positive coefficient of TV consumption $(p<0.1)$ emerged.

Table 4. Personal goals and TV viewing (OLS)

\begin{tabular}{lllllll}
\hline \multicolumn{7}{c}{ Dependent variable } \\
\hline $\begin{array}{l}\text { Independent } \\
\text { variable }^{\mathrm{a}}\end{array}$ & $\begin{array}{l}\text { Self- } \\
\text { acceptance } \\
\text { and } \\
\text { affiliation }\end{array}$ & $\begin{array}{l}\text { Community } \\
\text { feeling }\end{array}$ & $\begin{array}{l}\text { Physical } \\
\text { fitness }\end{array}$ & $\begin{array}{l}\text { Financial } \\
\text { success }\end{array}$ & $\begin{array}{l}\text { Attractive } \\
\text { appearance }\end{array}$ & $\begin{array}{l}\text { Social } \\
\text { recogni- } \\
\text { tion }\end{array}$ \\
\hline $\begin{array}{l}\text { Television } \\
\text { Hours of } \\
\text { viewing } \\
\text { (daily) }\end{array}$ & -0.0045 & -0.0120 & -0.0046 & $0.0349 *$ & 0.0219 & 0.0040 \\
Observations & 476 & 476 & 476 & 476 & 476 & 476 \\
$\mathrm{R}^{2}$ & 0.2056 & 0.0779 & 0.0508 & 0.0970 & 0.0836 & 0.1187 \\
\hline
\end{tabular}

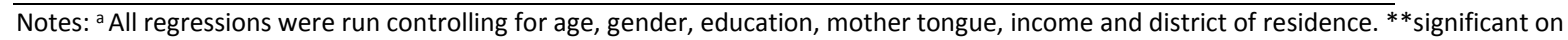
$99 \%$ level, ${ }^{*}$ significant on $95 \%$ level, $(*)$ significant on $90 \%$ level.

The hypothesis that personal goals mediate the relationship between television consumption and sustainable attitudes was further explored with a Sobel test to determine whether the reduction in the coefficient of the television viewing variable in specification (b) was statistically significant (Sobel, 1982). Table 5 presents the results of the mediational study, confirming that the differences in the coefficients for television viewing in models (a) and (b) are statistically significant, with a $94.4 \%$ level of confidence (z-test Sobel). The output of the mediational study in the STATA programme also shows that full mediation cannot be confirmed, as only $27 \%$ of the total effect is mediated through the goal of financial success.

Table 5. Mediating role of the goal of financial success on relationship between TV viewing and sustainable attitudes

\begin{tabular}{llcc}
\hline Independent variable & Dependent variable & Coefficient & t-Value \\
\hline $\begin{array}{c}\text { First regression } \\
\text { Television, hours } \\
\text { Second regression } \\
\begin{array}{c}\text { Television, hours } \\
\text { Third regression }\end{array}\end{array}$ & Sustainable attitudes & $-0.013^{*}$ & -2.22 \\
$\begin{array}{l}\text { Television, hours } \\
\text { Financial success }\end{array}$ & Sustainable attitudes & $0.026^{*}$ & 1.99 \\
$z$-test Sobel & & $-0.010(*)$ & -1.70 \\
Television, hours & & $-0.134^{* *}$ & -6.81 \\
\hline
\end{tabular}

Notes: (1) ${ }^{* *}$ significant on $99 \%$ level, ${ }^{*}$ significant on $95 \%$ level, $\left({ }^{*}\right)$ significant on $90 \%$ level.

\subsection{Robustness checks}

The cross-sectional nature of the data raises the problem of endogeneity concerning reverse causation (that the causal relationship runs both from television viewing to the dependent variable and/or vice versa), and omitted-variable bias (that misspecification of the model leads to television viewing being correlated to the error term). Regarding the marginal but positive coefficient of television viewing in specification (b), it is difficult to say that a happier person will decide to watch more hours of television (reverse causation) as most studies argue precisely the opposite (Kubey and Csikszentmihalyi, 1990; Stanca 2016). However, reverse causation could be problematic as regards 
the pathway from television viewing to happiness and sustainable attitudes through the goal of financial success. Arguably, the unhappy/less sustainably oriented respondents in the sample might value monetary pursuits more highly than their happier/more sustainably oriented counterparts, and in turn could spend more time watching television. Nevertheless, the fact that previous experimental evidence finds that causality runs from television viewing to personal goals or values, and from personal goals to pro-environmental attitudes and subjective wellbeing, weakens the argument for reverse causation concerning the mediated model (Kasser, 2016; Sheldon et al., 2011; Shrum et al., 2011). Lastly, the existence of a common causal factor not included in the models cannot be discarded, even though all the relevant controls in previous similar studies have been accounted for.

To investigate the robustness of the findings concerning subjective wellbeing, specifications (a) and (b) were re-run using as dependent variables answers to the life satisfaction question and the subjective vitality scale described in section 3.1. This analysis was also meant to make the findings more comparable with those of previous studies on the relationship between television consumption and SWB, as these have generally used life satisfaction as the dependent variable (see Kataria and Regner 2010 and Stanca 2016 for a review). As presented in Table A.3 in the appendix, television viewing did not emerge as a significant predictor of life satisfaction or subjective vitality in specification (a). However, when goal subscales were included in the model, the coefficient of television consumption became positive and significant in the regression explaining subjective vitality. The fact that the goal for financial success was a significant negative predictor of the two subjective wellbeing variables, and that it suppressed the positive effect of television viewing on vitality as it did with happiness, added robustness to results of the happiness study.

\section{Conclusions and policy implications}

This study has explored the contribution of television consumption to environmental sustainability by examining the relationship between television viewing, sustainable attitudes and happiness in Peru. The extent to which television viewing predicts sustainable attitudes has been explored, accounting for the direct and indirect effects of the activity. As expected from previous studies, television viewing emerged as a negative predictor of sustainable attitudes. The higher the consumption of television, the lower were respondents' preferences for scenarios involving environmentally sustainable practices. However, this negative association was not confirmed with regard to subjective wellbeing, as more hours of viewing failed to emerge as a significant predictor of happiness, of subjective vitality, or of life satisfaction (the SWB variable most commonly used in studies on television consumption and wellbeing). Concerning the indirect effects of television viewing - and as predicted - an increase in consumption was found to be associated with greater emphasis on the goal of financial success, which in turn was a negative predictor of sustainable attitudes and subjective wellbeing. Results of the mediational study presented in section 4 indicated that the goal of financial success partially mediated the negative effect of television viewing on sustainable attitudes. That was not the case for wellbeing: when personal goals were controlled for in the regression, the relationship between viewing and two of the measures of subjective wellbeing became positive, indicating that the goal of financial success might be acting as a suppressor and not as a mediator (MacKinnon et al., 2007).

The main result of this study concerns the fact that greater consumption of television reduces individuals' sustainable attitudes but not their wellbeing, except for its contribution to prioritizing financial success - a negative determinant of happiness, life satisfaction and subjective vitality. This is not surprising, as the negative relationship between television consumption and pro-environmental attitudes as identified in the literature is explained by the lack of environmental content of mainstream television programmes and the prevalence of materialistic messages - a characteristic of television across countries and regions (Galhardi et al., 2015; Kottak, 2016; Martinez Garza, 2005; McComas et al., 2001; Shanahan and McComas', 1999). In contrast, the relationship between TV viewing and wellbeing seems to depend on the socio-economic and infrastructural characteristics of 
the country in question (Graham and Nikolova 2013; Kataria and Regner 2010). The sample analysed in this study was chosen to reflect geographic, socio-economic and cultural diversity in Peru (Copestake 2008; Guillen-Royo and Kasser 2015). Still, there was no indication that the relationship between television viewing and wellbeing was negative in any of the districts, when an interaction term was included in the study and model (b) was replicated by district. This, together with the fact that television is still the type of media most often used for entertainment and news in Peru (CONCORTV,2015), would indicate that television remains important across socio-economic groups and that it might not necessarily reduce wellbeing - except perhaps through its promotion of materialistic values and goals.

The direct effects of television consumption in Peru can be interpreted in terms of a trade-off variable: a consumption practice that is beneficial or neutral for wellbeing but deleterious to environmental sustainability (Verhofstadt et al. 2016). However, the fact that viewing contributes to materialism brings television consumption closer to a lose-lose variable, negative as regards both sustainability and wellbeing. Lose-lose variables are identified by Verhofstadt and colleagues (2016) as deserving priority when sustainability interventions are designed. A promising avenue in this regard would be to address the values propagated through television programmes and advertising. Crompton and Kasser (2009) recommend, in addition to removing advertisements from public spaces, banning advertising aimed at children and increasing the taxes on television commercials, and raising public awareness through media literacy programmes. The latter are not widespread in Peru, where $48 \%$ of urban children report not having been taught how to analyse television messages (CONCORTV, 2016); such work will require the engagement of international organizations and NGOs involved in the promotion of environmental sustainability across socio-economic and geopolitical contexts.

In addition to tackling materialistic messages, regulators might want to engage stakeholders in discussions of how information on climate change, environmental impacts or nature conservation is conveyed on television. This is particularly important in countries where natural resource extraction is a major source of national revenue, as in Peru. Environmental organizations and indigenous groups campaigning for the rights of nature or demanding specific measures to reduce the environmental impact of mining or oil extraction are often portrayed as working against national interests. News programmes focus mainly on the conflict and violence surrounding environmentally related demands, and not on the natural spaces and habitats that could be conserved by slowing down the pace of extraction (Dahlstrom and Scheufele, 2010; Huaman, 2015). Television can be an ally for sustainability - but its content must be critically examined. As Smith (2017) has noted regarding the BBC's presentation of low-carbon lifestyles, audience preferences are central to the choice of programmes to broadcast. Framing environmentally-related stories with topics of general human concern (feelings, health and work, for example) may offer a promising way to increase their popularity.

\section{References}

Allwood, J.M., Ashby, M.F., Gutowski, T.G., Worrell, E. (2011) Material efficiency: a white paper. Resources, Conservation and Recycling 55, 362-381.

Andrews, F.M., Whitney, S.B. (1976) Social indicators of wellbeing: America's perception of life quality. Plenum, New York.

APEIM (Asociación Peruana de Empresas de Investigación de Mercado) (2011) Niveles socioeconomicos 2011. (http://www.apeim.com.pe/niveles.html, accessed 20.10.2012).

Baron, R.M., Kenny, D.A. (1986). The moderator-mediator variable distinction in social psychological research: conceptual, strategic and statistical considerations. Journal of Personality and Social Psychology 51, 1173-1182. 
Bechetti, L., Castriota S., Solferino, N. (2011) Development projects and life satisfaction: An impact study of Fair Trade handicraft producers. Journal of Happiness Studies 12, 114-138.

Bostic, T.J., Rubio, D.M., Hood, M. (2000) A validation of the subjective vitality scale using structural equation modelling. Social Indicators Research 52, 313-324.

Bruni, L., Stanca, L. (2008) Watching alone: Relational goods, television and happiness. Journal of Economic Behaviour \& Organisation 65, 506-528.

Burroughs, J.M., Shurm, L.J., Rindfleisch, A. (2002) Does television viewing promote materialism? Cultivating American perceptions of the good life. Advances in Consumer Research 29, 442-443.

Chilton, P., Crompton, T., Kasser, T., Maio, G., Nolan, A. (2012) Communicating bigger-than-self problems to extrinsically-oriented audiences. Common Cause report

(http://valuesandframes.org/downloads/, accessed 28.07.2017).

Clark, A. E., Frijters, P., Shields, M.A. (2008) Relative income, happiness, and utility. Journal of Economic Literature 95, 115-22.

Concortv (Consejo Consultivo de Radio y Televisión del Perú). (2013). Estudio de actitudes, hábitos y opinión sobre la radio y televisión 2013. (http://www.concortv.gob.pe/file/2013/estudios/2013estudio-radio-tv-concortv.pdf)

Concortv (Consejo Consultivo de Radio y Televisión del Perú) (2015) Consumo radial y televisivo 2015. (http://www.concortv.gob.pe/file/2015/resumen-estudio-2015.pdf)

Concortv (Consejo Consultivo de Radio y Televisión del Perú). (2016). Estudio cuantitativo sobre consumo televisivo y radial en niños, niñas y adolescentes. Lima, Perú: Concortv.

(http://www.concortv.gob.pe/wp-content/uploads/2017/04/Informe-final-estudio-NNA.pdf)

Concortv (Consejo Consultivo de Radio y Televisión del Perú). (2017). Estadísticas de la Radio y Televisión en el Perú 2017. (http://www.concortv.gob.pe/wp-content/uploads/2017/05/Estudioestadisticas-radio-tv-2017.pdf)

Copestake, J. (ed.) (2008) Wellbeing and Development in Peru: Local and Universal Views Confronted. Palgrave Macmillan, Basingstoke.

Crompton, T. and Kasser, T. (2009). Meeting Environmental Challenges: The Role of Human Identity. WWF-UK, Godalming.

Dahlstrom , M.F., Scheufele, D.A. (2010) Diversity of television exposure and its association with the cultivation of concern for environmental risks. Environmental Communication 4(1), 54-65.

Easterlin, R.A. (2013) Happiness and economic growth: The evidence. IZA DP No. 7187. January 2013.

Eid, M., Diener, E. (2004) Global judgments of subjective wellbeing: situational variability and longterm stability. Social Indicators Research 65, 245-277.

Ferrer-i-Carbonell, A., Frijters, P. (2004) How important is methodology for the estimates of the determinants of happiness? The Economic Journal 114, 641-659.

Fiske, J. (1987) Television Culture. Methuen, New York.

Frey, B.S., Stutzer, A. (2002) Happiness and Economics. Princeton University Press, Princeton, NJ.

Frey, B.S., Benesch, C., Stutzer, A. (2007) Does watching TV make us happy? Journal of Economic Psychology 28(3), 283-313.

Fuentes, C., Juárez, L., Mejía, L., Romero, K. Vizárraga, R. (2016) Lineamientos para el desarrollo de la television pública en el Perú. Serie Gerencia para el Desarrollo, 56. Universidad ESAN, Lima.

Galhardi, C., Mohedano, F., Peronsanz, J. J. (2015) Investigação dos fluxos comunicacionais no Brasil. Panorama da programação de televisão aberta no Estado de São Paulo em 2012: um estudo empírico. Intercom: Revista Brasileira de Ciências da Comunicação 38(1), 255-272. 
Gasper, D. (2005) Subjective and objective well-being in relation to economic inputs: Puzzles and responses. Review of Social Economy 63(2), 177-206.

Gavin, N.T. and Marshall, T. (2011) Mediated climate change in Britain: Scepticism on the web and on television around Copenhagen. Global Environmental Change 21, 1035-1044.

Gerbner, G. and Gross, L. (1976) Living with television: The violence profile. Journal of Communication 26(2), 173-199.

Good, J.E. (2007) Shop till we drop? Television, materialism and attitudes about the natural environment. Mass Communication and Society 10(3), 365-383.

Good, J.E. (2009) The cultivation, mainstreaming and cognitive processing of environmentalists watching television. Environmental Communication 3 (3), 279-297.

Graham, C. (2009) Happiness around the world. Oxford University Press, Oxford.

Graham, C. and Pettinato, S. (2002) Happiness and Hardship. Brookings Institution Press, Washington, DC.

Graham, C. and Nikolova. M. (2013) Does access to information technology make people happier? Insights from well-being surveys from around the world. The Journal of Socio-Economics 44, 126139.

Guillen-Royo, M. (2007) Consumption and wellbeing: Motives for consumption and needs satisfiers in Peru. PhD Thesis, University of Bath, UK.

Guillen-Royo, M. and Kasser T. (2015) Personal goals, happiness and socio-economic context:

Studying a diverse sample in Peru. Journal of Happiness Studies 16(2), 405-425.

Harmon, M.D. (2001) Affluenza: Television use and cultivation of materialism. Mass Communication and Society 4 (4), 405-418.

Herrera, J. Razafindrakoto, M., Roubaud, F. (2006) The determinants of subjective poverty: A comparative analysis between Madagascar and Peru. DIAL Document de travail, 2006-1.

Huaman, C. (2015) El rol social de la televisión de señal abierta en el país. BSc thesis, Universidad Peruana Simón Bolívar, Lima.

Hurst, M., Dittmar, H., Bond, R., Kasser, T. (2013) The relationship between materialistic values and environmental attitudes and behaviors: A meta-analysis. Journal of Environmental Psychology 36, 257-269.

Hyll, W. and Schneider, L. (2013) The causal effect of watching TV on material aspirations: Evidence from the 'valley of the innocent'. Journal of Economic Behavior \& Organization 86, 37-51.

Instituto Nacional de Estadistica e Informatica (INEI) (2010) Encuesta Nacional de Hogares sobre Condiciones de Vida y de Pobreza 2010.

(http://webinei.inei.gob.pe/anda_inei/index.php/catalog/197; accessed 06.12.17)

Instituto Nacional de Estadistica e Informatica (INEI) (2015a) Encuesta Nacional de Programas

Estratégicos, 2014-2015 (https://www.inei.gob.pe/prensa/noticias/de-cada-100-hogares-peruanos-

87-ven-television-8557/; accessed 31.05.2017).

Instituto Nacional de Estadistica e Informatica (INEI) (2015b). Encuesta Nacional de Hogares.

(https://www.inei.gob.pe/estadisticas/indice-tematico/sociales/; accessed 31.05.2017)

Instituto Nacional de Estadistica e Informatica (INEI) (2017). Estadísticas. (https://www.inei.gob.pe/; accessed 07.2017).

Jakoby, E., Goldstein, J., López, A., Núñez, E., López, T. (2003) Social class, family, and life-style factors associated with overweight and obesity among adults in Peruvian cities. Preventive Medicine 37(5), 396-405.

Kasser, T. (2002) The high price of materialism. MIT Press, Cambridge, MA.

Kasser, T. (2016) Materialistic values and goals. Annual Review of Psychology 67, 9.1-9.26. 
Kasser T. (2017) Living both well and sustainably: a review of the literature, with some reflections on future research, interventions and policy. Philosophical Transactions of the Royal Society A, 375: 20160369.

Kasser, T. and Ryan, R. M. (1993) A dark side of the American dream: Correlates of financial success as a central life aspiration. Journal of Personality and Social Psychology 65, 410-422.

Kasser, T. and Ryan, R. M. (1996) Further examining the American dream: Differential correlates of intrinsic and extrinsic goals. Personality and Social Psychology Bulletin 22, 281-288.

Kataria, M. and Regner, T. (2010) A note on the relationship between television viewing and individual happiness. Journal of Socio-Economics 40(1), 53-8.

Kottak, C.P. (2016) Prime-Time Society: An Anthropological Analysis of Television and Culture. Updated edition. Routledge, Abingdon.

Kubey, R. and Csikszentmihalyi, M. (1990) Television and the Quality of Life: How Viewing Shapes Everyday Experience. Lawrence Erlbaum Associates, Hillsdale, NJ.

Latinlink (2015) The latest on media consumption in Latin America.

(http://latinlink.usmediaconsulting.com/2013/10/the-latest-on-media-consumption-in-latinamerica/, accessed 28.07.2017)

Lenzen, M. and Cummins, R.A. (2013) Happiness versus the environment: a case study of Australian lifestyles. Challenges 4, 56-74.

Lopez-Calva, L. F. and Lustig, N. (eds) (2010) Declining Inequality in Latin America: A Decade of Progress? Brookings Institution and UNDP, Washington, DC.

MacKinnon, D.P., Fairchild, A.J., Fritz, M.S. (2007) Mediation analysis. Annual Review of Psychology 58, 593-614.

Martinez Garza, J. (2005) La oferta de televisión en América Latina: hacia un análisis de flujos. Revista de Estudios de Comunicación 19, 145-127.

Mateus, J. (2008) El mito de la pantalla que educa. Televisión y educación en el Perú: tensiones y posibilidades. La Mirada de Telemo 1.

(http://revistas.pucp.edu.pe/index.php/lamiradadetelemo/article/view/3489/3382, accessed 05.07.2017).

McBride, M. (2001) Relative-income effects on subjective well-being in the cross-section. Journal of Economic Behavior and Organization, 45, 251-278.

McComas, K.A., Shanahan, J., Butler, J.S. (2001) Environmental content in prime-time network TV's non-news entertainment and fictional programs. Society and Natural Resources 14 (6), 533-542.

Nairn, A., Ormrod, J., Bottomley, P. (2007) Watching, Wanting and Wellbeing: Exploring the Links. National Consumer Council, London.

Podsakoff, P.M., MacKenzie, S.B., Lee J-Y., Podsakoff, N.P. (2003) Common method biases in behavioral research: a critical review of the literature and recommended remedies. Journal of Applied Psychology 88, 879-903.

Poterico, J.A., Bernabe-Ortiz, A., Loret de Mola, C., Miranda J. Jaime (2012) Asociación entre ver television y obesidad en mujeres peruanas. Revista Saúde Publica 46 (4), 610-616.

Richins, M. L. and Dawson, S. (1992) A consumer values orientation for materialism and its measurement: Scale development and validation. Journal of Consumer Research 19, 303-16.

Ryan, R. and Frederick, C.M. (1997) On energy, personality and health: Subjective vitality as a dynamic reflection of well-being. Journal of Personality 65, 529-565.

Ryan, R. and Deci, E.L. (2001) On happiness and human potentials: A review of research on hedonic and eudaimonic well-being. Annual Review of Psychology 52, 141-166.

Sevillano, M.L. and Sotomayor, A. (2012) Publicidad y consumo de alimentos en estudiantes de Huánuco (Perú). Revista Científica de Educomunicación, 39, 188-184. 
Shanahan, J. and McComas, K. (1999) Nature stories: Depictions of the environment and their effects. Hampton Press, Cresskill, NJ.

Sheldon, K.M., Nichols, C.P., Kasser, T. (2011) Americans recommend smaller ecological footprints when reminded of intrinsic American values of self-expression, family, and generosity. Ecopsychology 3, 97-104.

Shrum, L.J., Burroughs, J.E., Rindfleisch, A. (2005) Television's cultivation of material values. Journal of Consumer Research 32, 473-479.

Shrum, L.J., Lee, J., Burroughs, J., Rindfleisch, A. (2011) An online process model of second-order cultivation effects: How television cultivates materialism and its consequences for life satisfaction. Human Communication Research 37, 34-57.

Sirgy, M.J., Lee, D-J., Kosenko, R., Meadow, H.L., Rahtz, D., Cicic, M., Jin, G.J., Yarsuvat, D., Blenkhorn, D., W., Wright, N. (1998) Does television viewership play a role in the perception of quality of life? Journal of Advertising 27(1), 125-142.

Smith, J. (2017) Demanding stories: television coverage of sustainability, climate change and material demand. Philosophical Transactions of the Royal Society A, 375: 20160375.

Sobel, M.E. (1982) Asymptotic confidence intervals for indirect effects in structural equation models. In: Leinhardt, S. (ed.) Sociological Methodology. American Sociological Association, Washington, DC, pp. 290-312.

Stanca, L. (2016) Happiness and the new media. In: Bruni, L., Porta, P.L. (eds), Handbook of Research Methods and Applications in Quality of Life. Edward Elgar, Cheltenham, pp.467-482.

United Nations (2015) Transforming our World: The 2030 Agenda for Sustainable Development. (https://sustainabledevelopment.un.org/post2015/transformingourworld; Accessed 30.05.2017)

United Nations Framework Convention on Climate Change (2015) Adoption of the Paris Agreement, 21st Conference of the Parties. United Nations, Paris.

Verhofstadt, E., Van Ootegem, L.V., Defloor, B., Bleys, B. (2016) Linking individuals' ecological footprint to their subjective well-being. Ecological Economics 127, 80-89.

Wooldridge, J.M. (2013) Introductory Econometrics. A Modern Approach. Fifth international edition, South Western College Publishing, Mason, $\mathrm{OH}$.

World Bank (2017) World Bank list of economies (March 2017).

(databank.worldbank.org/data/download/site-content/CLASS.xls; accessed 30.05.2017)

Appendix

Table A.1 Descriptive statistics for control and independent variables

\begin{tabular}{|c|c|c|c|c|c|c|}
\hline Variable & Description & Obs. & Mean & SD & Min & Max \\
\hline & Television & & & & & \\
\hline \multirow[t]{2}{*}{$\begin{array}{l}\text { Hours of } \\
\text { viewing }\end{array}$} & Number of hours watching television per day & 492 & 2.66 & 2.20 & 0 & 18 \\
\hline & Goals & & & & & \\
\hline $\begin{array}{l}\text { Self- } \\
\text { acceptance } \\
\text { and } \\
\text { affiliation }\end{array}$ & Average score of the 8 items loading on this subscale & 500 & 3.92 & 0.45 & 2.29 & 5 \\
\hline
\end{tabular}




\begin{tabular}{|c|c|c|c|c|c|c|}
\hline $\begin{array}{l}\text { Community } \\
\text { feeling }\end{array}$ & Average score of the 6 items loading on this subscale & 500 & 3.86 & 0.50 & 1.83 & 5 \\
\hline $\begin{array}{l}\text { Physical } \\
\text { fitness }\end{array}$ & Average score of the 5 items loading on this subscale & 500 & 3.86 & 0.52 & 2 & 5 \\
\hline $\begin{array}{l}\text { Financial } \\
\text { success }\end{array}$ & Average score of the 5 items loading on this subscale & 500 & 2.87 & 0.63 & 1 & 4.6 \\
\hline $\begin{array}{l}\text { Attractive } \\
\text { appearance }\end{array}$ & Average score of the 4 items loading on this subscale & 500 & 2.86 & 0.73 & 1 & 5 \\
\hline \multirow[t]{2}{*}{$\begin{array}{l}\text { Social } \\
\text { recognition }\end{array}$} & Average score of the 6 items loading on this subscale & 500 & 2.60 & 0.80 & 1 & 4.6 \\
\hline & Personal characteristics & & & & & \\
\hline Age & Participant's age in years & 500 & 40.30 & 17.31 & 18 & 95 \\
\hline Female & Gender dummy: 1 if female & 500 & 0.53 & 0.50 & 0 & 1 \\
\hline $\begin{array}{l}\text { Civil status } \\
\text { (cohabiting) }\end{array}$ & Cohabiting dummy: 1 if married or living with partner & 500 & 0.46 & 0.50 & 0 & 1 \\
\hline $\begin{array}{l}\text { Civil status } \\
\text { (Separated/D } \\
\text { ivorced) }\end{array}$ & Separated dummy: 1 if divorced or separated & 500 & 0.10 & 0.30 & 0 & 1 \\
\hline $\begin{array}{l}\text { Civil status } \\
\text { (Widowed) }\end{array}$ & Widowed dummy: 1 if widowed & 500 & 0.04 & 0.21 & 0 & 1 \\
\hline Health status & $\begin{array}{l}\text { Self-reported health status: from } 1 \text { if 'very bad' to } 5 \text { if } \\
\text { 'very good' }\end{array}$ & 500 & 3.58 & 0.81 & 1 & 5 \\
\hline $\begin{array}{l}\text { Education } \\
\text { (no level) }\end{array}$ & No education level dummy: 1 if no formal education & 500 & 0.03 & 0.18 & 0 & 1 \\
\hline $\begin{array}{l}\text { Education } \\
\text { (primary) }\end{array}$ & $\begin{array}{l}\text { Primary education dummy: } 1 \text { if completed primary } \\
\text { school }\end{array}$ & 500 & 0.09 & 0.29 & 0 & 1 \\
\hline $\begin{array}{l}\text { Education } \\
\text { (secondary) }\end{array}$ & $\begin{array}{l}\text { Secondary education dummy: } 1 \text { if completed } \\
\text { secondary school }\end{array}$ & 500 & 0.27 & 0.42 & 0 & 1 \\
\hline $\begin{array}{l}\text { Education } \\
\text { (higher non- } \\
\text { university) }\end{array}$ & $\begin{array}{l}\text { Higher non-university education dummy: } 1 \text { if } \\
\text { completed higher non-university studies }\end{array}$ & 500 & 0.24 & 0.43 & 0 & 1 \\
\hline $\begin{array}{l}\text { Education } \\
\text { (postgrad) }\end{array}$ & $\begin{array}{l}\text { Postgraduate education dummy: } 1 \text { if completed } \\
\text { postgraduate education }\end{array}$ & 500 & 0.07 & 0.25 & 0 & 1 \\
\hline \multirow[t]{2}{*}{$\begin{array}{l}\text { Mother } \\
\text { tongue }\end{array}$} & Language dummy: 1 if mother tongue is Quechua & 500 & 0.23 & 0.42 & 0 & 1 \\
\hline & Income & & & & & \\
\hline \multirow[t]{2}{*}{$\begin{array}{l}\text { Personal } \\
\text { income }\end{array}$} & Natural logarithm of household income per capita & 482 & 6.57 & 1.30 & 3.69 & 9.77 \\
\hline & Location & & & & & \\
\hline $\begin{array}{l}\text { Breña, } \\
\text { Huaycan, }\end{array}$ & 1 if respondent lives in the district & 500 & 0.2 & 0.40 & 0 & 1 \\
\hline
\end{tabular}


Huancayo,

Acostambo

Note: Reference group for civil status is single, for education is university graduate and for location is the district of Miraflores.

Table A.2 Television viewing, sustainable attitudes and happiness (OLS)

\begin{tabular}{|c|c|c|c|c|}
\hline \multirow[b]{2}{*}{ Independent variable ${ }^{a}$} & \multicolumn{2}{|c|}{ Sustainable attitudes } & \multicolumn{2}{|c|}{ Happiness } \\
\hline & $\begin{array}{l}\text { With } \\
\text { quadratic } \\
\text { term }\end{array}$ & $\begin{array}{l}\text { With } \\
\text { categorical } \\
\text { variable }\end{array}$ & $\begin{array}{l}\text { With } \\
\text { quadratic } \\
\text { term }\end{array}$ & $\begin{array}{l}\text { With } \\
\text { categorical } \\
\text { variable }\end{array}$ \\
\hline Television & & & & \\
\hline Hours of viewing (daily) & $-.0258 * *$ & & .0041 & \\
\hline Hours of viewing*hours of viewing & $.0018^{*}$ & & .0031 & \\
\hline No television watching ${ }^{\mathrm{b}}$ & & .0181 & & 1844 \\
\hline More than 2.7 hours $^{b}$ & & $-.0789 * *$ & & .0100 \\
\hline Observations & 468 & 473 & 475 & 480 \\
\hline $\mathrm{R}^{2}$ & 0.0980 & 0.0991 & 0.1073 & 0.1066 \\
\hline
\end{tabular}

Table A.3 Television viewing, life satisfaction and subjective vitality (OLS)

\begin{tabular}{|c|c|c|c|c|}
\hline \multirow[t]{2}{*}{ Independent variable ${ }^{a}$} & \multicolumn{2}{|c|}{ Subjective vitality } & \multicolumn{2}{|c|}{ Life Satisfaction } \\
\hline & (a) & (b) & (a) & (b) \\
\hline \multicolumn{5}{|l|}{ Television } \\
\hline Hours of viewing (daily) & .0153 & $.0221 *$ & -.0068 & -.0018 \\
\hline \multicolumn{5}{|l|}{ Personal goals } \\
\hline Self-acceptance and affiliation & & -.0664 & & .2109 \\
\hline Community feeling & & $.2886^{* *}$ & & -.0096 \\
\hline Physical fitness & & .0911 & & $-.1910 *$ \\
\hline Financial success & & $-.1549 * *$ & & $-.2886 * *$ \\
\hline Attractive appearance & & $.1009 *$ & & $.2140^{*}$ \\
\hline Social recognition & & .0303 & & .0801 \\
\hline Observations & 475 & 475 & 473 & 473 \\
\hline $\mathrm{R}^{2}$ & 0.1566 & 0.2435 & 0.0866 & 0.1238 \\
\hline
\end{tabular}

Notes ${ }^{\text {a }}$ All regressions were run controlling for age, gender, education, mother tongue, income and district of residence. ${ }^{* *}$ significant at $99 \%$ level, ${ }^{*}$ significant at $95 \%$ level, $\left({ }^{*}\right)$ significant at $90 \%$ level. 